\title{
DRIVERS OF RELATIONSHIPS AFFECTING B2B FIRMS IN AN E-
} COMMERCE ENVIRONMENT

Irene Samanta
Assistant Professor
Technological Institute of Piraeus, Greece
E-mail: irinisamanta@gmail.com
Professor Mike Danson
School of Management and Languages Heriot-Watt University,
Scotland
E-mail: m.danson@hw.ac.uk
Submission: $10 / 11 / 2013$
Revision: $24 / 11 / 2013$
Accept: 06/03/2014

\section{ABSTRACT}

The advent of the internet has created numerous opportunities for B2B marketing professionals to enhance current marketing practices, including electronic relationships. However, the investigation of erelationships and the factors that influence e-relationships in an internet environment is scant. Further, there appears to be no investigation of this phenomenon within the context of Greek B2B Medium-sized firms (MSF). The research problem investigated in this research is: "Which drivers in $\mathrm{B} 2 \mathrm{~B}$ e-commerce use affect inter-firm relationships in medium-sized B2B firms?". A framework for B2B e-commerce relationships in a changing and globalized environment was synthesized and integrated with the literature about relationship marketing to arrive at the following research issues: "How do relationship marketing drivers affect the management of B2B erelationships?"

An explanatory quantitative research approach was used and quantitative data was collected from B2B firms in Greece, which represents a case of e-commerce progress during the last six years. Regarding social exchange, some important differences emerge where cooperation between B2B e-commerce firms is concerned. Suppliers engaged in electronic commerce are more committed and oriented to a 
long-term relationship than buyers, based on both previous and current experience with them. Confidence in the relationships, consistency and honesty with their obligations and the exchange of reliable, trustworthy information and advisory services between firms are important factors in the development and establishment of their e-relationships.

The main contribution of this research is the development of e-relationships in medium-sized B2B firms. That framework is the first rigorously researched step towards understanding the importance of these powerful streams of relationship drivers in total, and the business activity of e-marketing and electronic relationships.

Keywords: B2B relationships, trust, adaptation, commitment, e-commerce.

\section{INTRODUCTION}

B2B internet marketing has received widespread attention as one of the key drivers in sustaining an organization's competitive advantage. On the other hand, the development of internet usage has experienced transformations, particularly in the area of the expectations of organizations for creating value within a supply chain. This allows businesses to extend their relationships with customers, suppliers, retailers, brokers, co-producers, employees and shareholders and achieve a more personalized relationship with them (SAMIEE, 1998). The development of such personalized relationships is a key goal of marketing, because they tend to be more sustainable. In the second decade of the new millennium, e-commerce is marked by innovations which are making online transactions easier (FORESTER RESEARCH, 2010).

Firms are investing their newfound profits in emerging technologies, such as sophisticated analytical and personalization tools that enhance the online experience for existing customers. The result is that businesses no longer view the Web as a low-cost sales channel but as a way of improving customer service and retention. As online commerce continues to grow overall, customer expectations for B2B ecommerce are also changing rapidly. Companies serving business buyers are realizing that the old ways of conducting business are no longer sufficient. B2B companies that wish to grow and become more profitable are looking to adopt ecommerce. 
DOI: 10.14807/ijmp.v5i3.164

As Forrester Research explains, "e-commerce platforms have a relatively low cost but high return on investment in the spectrum of enterprise IT projects and support a new or maturing revenue stream that meets the needs of a changing customer" (FORRESTER RESEARCH, 2010).

Regarding Greece, a new report by the World Economic Forum ranks countries in the period 2010-11 with respect to the introduction and utilization of new information technologies, networks and telecommunications; Greece occupies the 64th position among 138 countries. Greece is still technologically far from the northern countries that monopolize the research and technology industry, spending large sums of money. More specifically, Greece has low access to the new economy in B2B transactions and the society of information of all the countries in the European Union, given that it has low expenditure on research and technology.

Greece, although it lags behind other European countries regarding the penetration of new technologies, is starting to show signs of development in B2C transactions (http://www.go-online.gr, date of accessing 11/12/2011). The penetration of broadband internet in the Greek population, 2,252,653 individuals in 2011 are online, certainly contributes significantly to developing B2C transactions, and this is because the prices of broadband in the country are relatively low compared with the rest of Europe (www.tradingeconomics.com, date of accessing 13/12/2011).

In order to meet the expectations and changes in the business environment in an economic crisis period, the contemporary medium-sized companies in Greece have to react frequently and quickly to this new business environment by accepting an innovation culture and undertaking actions in response to business pressures. As a conclusion, the new economy seems to be changing the world dramatically. It is creating new possibilities for development in countries such as Greece. It is creating a global economy obliging everyone to be properly prepared to confront the pressures of international competition. The responsibilities of both the state and the business world are immense and any delays will have a negative effect on both industry and government.

However, for a framework for the role of business today in a changing globalized environment, the shift from the "old" to the "new" world of B2B relationships in an e-business context, the strategic features of buyer-supplier 
DOI: 10.14807/ijmp.v5i3.164

relationships and relationship marketing in the extant literature were integrated and synthesized with the literature to arrive at the research objective below: to investigate the impact of e-relationship marketing drivers on the management of B2B erelationships. To address this objective, the paper first reviews the literature on B2B medium-sized firms of e-commerce before considering business relationships and erelationships especially.

The quantitative research methodology is introduced next with 120 businesses surveyed divided into 60 traditional and 60 e-commerce businesses with 30 buyers and 30 sellers in each group. The data are explored using regression analyses to examine relationships, commitment, trust and adaptation, and then policies and practices. The conclusions are enhanced by considering the implications for management and how the research can be extended.

\section{LITERATURE REVIEW}

\subsection{The effect of e-commerce in B2B medium-sized firms}

In the 1980s, market analysts had predicted that the influence of e-commerce would be more pronounced on Business to Business (B2B) rather than Business to Consumer (B2C) transactions (KLEIN; QUELCH, 1997; SAMIEE, 1998). Forrester (2006) estimated that, by 2008, B2B online exchanges would account for around $55 \%$ of worldwide e-commerce. The global nature of e-commerce would serve to increase both the number of potential B2B relationships and a company's customer base, which may contribute to achieving a sustainable competitive advantage.

In this context, the organizational structure of B2B medium-sized firms could adjust or change to suit the changing environment with a strategic vision for utilizing internet technologies (EID, et al., 2006; ALBRECHT, et al., 2005). Also, Barry et al., (2008) support the view that the way in which a business adapts to the changes in the business environment and addresses each of these marketing strategies has an impact on its B2B relationships and it is therefore important that this is sufficiently assessed by the organization (DEMARTINO, et al., 2006). Within such a strategy, in order for B2B firms to plan successfully and achieve materialization of the activities of electronic marketing, a specific purpose is needed (SAMANTA, 2006).

Some purposes behind having an electronic presence can be the modulation of relationships between buyer-seller and the rest of the members of the distribution 
DOI: 10.14807/ijmp.v5i3.164

network, and cooperation with other industries (SAMANTA, 2008). Consequently, firms must either choose to continue to exist using their present strategy, following the standards of the second industrial revolution, or adapt their operations to the new era, and this implies operating in markedly different ways.

So, Samanta (2008) states that firms moving from traditional commerce to ecommerce have to recognize that operating in an e-context is characterized by high competition comprising high frequency and informality of communications, short product life cycles, product design sophistication, consistent high quality, cost reductions, and customization and standardization. Managers conducting business online have and require more complete information in order to make effective decisions under circumstances of high competitive intensity. Therefore, firms need to constantly monitor market shifts and diversify products or processes proportionately.

As Quelch and Klein (1996) noted, firms who want to undertake e-business internationally have to redefine their operations, strategies, and business models in order to develop the opportunities offered by the internet to their full potential. Duggan and Devenery (2000) and Samiee (1998) claim that an organization must conceive and comply with e-business, management procedures and communication forms and strategies, with the applied aim to associate innovation with business targets, and the application of innovation values into the firm's internal environment.

Nevertheless, in a study by the OECD (2006), it was found that $60 \%$ of B2B ecompanies experienced difficulties arising from differences in business practices across countries. Therefore, B2B online enterprises should not underestimate the potential complexities (e.g. geographic, infrastructural, political, cultural, etc.) of success in global markets. There is a growing trend for some companies to refuse to transact with companies that do not use e-commerce in their operations, which shows the importance of using e-commerce in a B2B relationship (STOCKDALE; STANDING, 2004).

According to Porter (2001), the weakness of integration of the electronic with the natural activities of the strategic frame of operational development comprises one of the main causes of the failure of electronic markets. Moreover, many industries have not succeeded in understanding the strategic environment of the internet and 
DOI: 10.14807/ijmp.v5i3.164

have tried to operate their electronic expressions with mechanisms of the natural market, a fact that led quickly to operational failures.

\subsection{Trends driving relationships}

In a globalized market, information technology has made the development of electronic relationships possible. In the complex network of processes of globalization, local and global activities are linked together and operate in several directions. Globalization has thus transformed traditional business models through the advances in information technology (IT), networks and relationships.

Castells (2005) argues that this 'new economy' is fundamentally distinct from the traditional model, in that success now depends upon the effective use of information (knowledge), the implementation of global concepts (business organized on a global scale) and the creation of networks among economic agents (including interaction among various business networks). It has become clear that the traditional concept of business is no longer viable and needs revised.

Innovation and technological developments have significantly affected business concepts, models and paradigms. Peppers and Rogers (1995) claim that the marketplace is undergoing a technology-driven metamorphosis. In the past, firms were able to maintain their customers through traditional face-to-face interaction. However, because businesses now operate across international borders they are no longer able to satisfy the instant service requirements of customers and suppliers. Technology serves as a powerful tool to improve the efficiency and effectiveness of firms. However, as Berry (1983) argues, that technology should empower its users with greater control in achieving their aims.

Thus, the focus should be the creative adoption of technology to enhance the value of a firm's offerings. Hence, technological innovation must be translated into marketing foresight that enables a firm to 'think like a customer', thus creating services that drive the marketplace. In this respect, interactivity, a key attribute of the internet, provides unique opportunities in the field of marketing (DEIGHTON, 1997). Speed and efficiency are key benefits for buyers who are increasingly engaging in self-service technologies, as opposed to the more time-consuming face-to-face alternatives. 
DOI: 10.14807/ijmp.v5i3.164

Computer-mediated business transactions on the internet provide numerous opportunities for procurement and other services, including marketing, communication and distribution. Globalization has fundamentally reshaped marketing strategies via the internet and $\mathrm{B} 2 \mathrm{~B}$ firms today use the internet to extend their relationships with tens of thousands of entities, including customers, suppliers, retailers, brokers, co-producers, employees and shareholders, and try to maintain personalized relationships with them all.

\subsection{Managing buyer-supplier relationships}

Nurturing and managing customer relationships have emerged as important strategic priorities in most firms, first because loyal customers are far more profitable than customers who are price sensitive and perceive few differences among alternative offerings and, second, because a firm that is successful in developing strong relationships with customers secures important and durable advantages that are hard for competitors to understand, copy or displace. Therefore, the ability of an organization to create and maintain profitable relationships with its most valuable customers is a durable basis for a competitive advantage.

Building and maintaining lasting customer relationships require organizations to pay careful attention to detail, meet promises and respond swiftly to new requirements (BOWMAN; NARAYANDAS, 2004).

The new era of business marketing is built upon effective relationship management. Many business marketing firms create what might be called a collaborative advantage by demonstrating special skills in managing relationships with key customers or by jointly developing innovative strategies with alliance partners. These firms have learned how to be good partners, and these superior relationship skills are a valuable asset. Buyer-supplier relationships can be managed with the involvement of the consideration of different relationship types as not all relationships have the same intensity. Descriptions of certain relationship types are helpful in the context of the relationships label, such as competitive/collaborative, adversarial/allied, and tactical/strategic and short/long (WRIGHT, 2004).

\subsection{Factors influence e-relationships}

Developing the theoretical issues and the constructs that may influence B2B e-relationships leads to several factors being identified: communication, trust, 
DOI: 10.14807/ijmp.v5i3.164

satisfaction, commitment, dependence and adaptation. These constructs have been empirically tested in a non-e-commerce environment. Each is now defined for the specifics of this research below.

\subsubsection{Trust}

Trust is an important factor in $\mathrm{B} 2 \mathrm{~B}$ relationships because these relationships are often very important and fragile (HARKER, 1999). Ultimately, as building relationships has become the key in marketing, trust is becoming imperative (DWYER, et al., 1987). Essentially, trust refers to transactions between partners' confidence and reliability (BELL, 1995; DWYER, et al., 1987; ROTTER, 1967). Many relationship marketing researchers have defined trust (ANDERSON; WEITZ, 1992, ANDERSON, et al., 1994, DONEY; CANNON, 1997; MOORMAN, et al., 1993).

In these definitions, trust is viewed as the belief that a partner will perform actions that will result in positive outcomes for the firm and not take unexpected actions that may result in negative outcomes. Trust is considered the keystone of strategic partnerships, and it seems to be a mediating or intermediary element in buyer-seller relationships (DWYER, et al., 1987; SPEKMAN, 1988). A conceptual study (GWINNER, et al., 1998) and empirical studies (GARBARINO; JOHNSON, 1999; RATNASINGAM, 1998) have found trust to be the essential issue of the relational approach and consider it key to the development of the notion of commitment in buyer-seller relationships.

Trust is also viewed as a key element in establishing lasting relationships with customers and in maintaining a company's market share. It is also important to note that trust is not always two-way or mutual; just because partner A trusts partner B at one point in time does not mean it is reciprocal (HARKER, 1999).

As in all relationships, the nature of trust can change over time and also from situation to situation. By contrast, technology trust has been defined as the subjective probability by which an organization believes that the underlying technology infrastructure and control mechanisms are capable of facilitating inter-organizational transactions according to its confident expectations (RATNASINGAM; PAVLOU, 2003).

As technology use has increased in B2B networks, technology trust has become an important issue that must be addressed. Some of the requirements to 
DOI: 10.14807/ijmp.v5i3.164

ensure technology trust include confidentiality, integrity, authentication, nonrepudiation, access controls, availability and best business practices (RATNASINGAM; PAVLOU, 2003).

\subsubsection{Satisfaction}

Satisfaction is important in an exchange relationship (HAN, et al., 1993; WILSON, 1995) and marketing success. Process-oriented theories posit that satisfaction is the result of the comparison between expectations and actual performance (STRAUSS; FROST, 1999). In turn, outcome-oriented theories are asserted that satisfaction is an end-state that does not always rely on expectations being met (SPRENG, et al., 1996). Perceived value refers to the perceived level of product quality relative to the price paid and is achieved when the proper function is secured for the proper cost (ZEITHAML, et al., 1996). In this study, satisfaction is defined as the buyer's general level of satisfaction based on all experiences with the seller.

\subsubsection{Commitment}

Closely linked with trust and satisfaction is commitment, the third variable that operationalizes relationship marketing that attracts much attention in the literature (MORGAN; HUNT, 1994). In an exchange relationship, mutual commitment is the key construct for developing and maintaining a stable and enduring long-term relationship (GANESAN, 1994; JAP; GANESAN, 2000; WETZELS, et al., 1998). In other words, a relationship is more likely to thrive if both parties are committed to it and see it as an important part of future strategy (ANDERSON; WEITZ, 1992; PICK, 1999; SPEKMAN, 1988; WEITZ; JAP, 1995).

Commitment is recognized as an ingredient of successful long-term relationships (DWYER, et al., 1987; MORGAN; HUNT, 1994; GUNDLACH, et al., 1995). It is so important that it is claimed to be the "focal point of explanation in marketing, as the discipline moves further away from the transactional view of exchange and embraces the relational view" (GUNDLACH, et al., 1995: 78). Morgan and Hunt (1994) define commitment as the desire of an exchange partner to maintain a valued relationship and the belief that the relationship is worth working on to ensure that exchange continues indefinitely. 
DOI: 10.14807/ijmp.v5i3.164

There seem to be three views on the definition of commitment: calculative, temporal and affective. Calculative commitment is based on inputs such as investment and the allocation of resources specifically for the relationship between two businesses (WILLIAMSON, 1985). In other words, a firm is motivated to continue the relationship because it cannot easily replace its current partner or obtain the same resources and outcomes outside its current relationship (KUMAR, et al., 1994).

Temporal commitment occurs as a result of an expectation of continuity. Longterm relationships lead to a four-shortening in the learning curve, require simpler structures and consume less time (HEIDE; JOHN, 1990; GUNDLACH, et al., 1995). Affective commitment represents an exchange partner's affection for, and obligation to, its partner and indicates that the tie to the organization is not simply based on economic motivations. It is brought about by a person sharing, identifying with or internalizing the values of the organization (MORGAN; HUNT, 1994).

\subsubsection{Adaptation}

The level of adaptation of one partner to another is considered to be an important feature of the relationship because, in a business relationship, exchange partners often adapt to each other for limited resources, specialized knowledge, information and marketing assistance (ANDERSON; NARUS, 1990; BERRY; PARASURAMAN, 1991; GUNDLACH; CADOTTE, 1994; SMITH; BARCLAY, 1997).

Adaptation concerns the firm's need to maintain the relationship in order to achieve its desired goals (CANNON; HOMBURG, 2001; GANESAN, 1994). The definition proposed by Ganesan (1994: p. 3) is appropriate in this research because it fits its context: "the degree to which a firm needs to maintain its relationship with an exchange partner in order to achieve desired goals".

\subsubsection{Relationship policies and practices}

Relationship policies and practices represent one of the most important dimensions during a relationship process (JAP; GANESAN, 2000). By establishing clear relationship policies and practices, the supplier becomes motivated to behave in a way that is beneficial to the relationship as a whole, and as a result, "emerging exchange partners start setting the ground rules for future exchange" (DWYER, et al., 1987: p. 17). 
DOI: 10.14807/ijmp.v5i3.164

Despite the well-recognized significance of such policies, few studies have examined company behaviors and practices specifically or the mechanisms by which they strengthen a relationship. Nevertheless, it is recognized that relationship policies and practices should include ethical values, such as the supplier showing respect for customers, because they contribute to the development of the relationship between firms and customers (MORGAN; HUNT, 1994).

Having identified the constructs of communication, trust, satisfaction, commitment, dependence and adaptation as being key drivers in B2B e-commerce relationships, it was necessary to explore their importance empirically. The context to undertake this was Greece in the mid-2000s, a period when the economy was expanding and enterprises were developing innovative and new ways of working in a large and growing European market.

\section{RESEARCH METHODOLOGY}

The research focused on those B2B medium sized firms that have moved into and operate in e-commerce, examining the marketing and logistics elements. Quantitative, numeric data were collected, using a face-to-face-based survey of one hundred and twenty (120) B2B firms. To identify the potential B2B firms, two hundred and twenty five (225) firms were contacted. Using a snowball approach, every company that agreed to participate as a buyer or as a seller was asked to propose other firms to take part. At the end of the process, the sample comprised one hundred and twenty (120) companies.

The split amongst those is as follows: 60 make use of e-commerce (60-ecommerce) and the remaining 60 do not make use of e- commerce (60-traditional). Amongst the 60 -e-commerce companies 30 are buyers and 30 are sellers/suppliers. We have the same type split amongst the 60-traditional companies. The model of the sample logic, which was used for the second stage of quantitative research, is presented in detail in Figure 3.1.

A number $x$ of firms that operate in an e- commerce environment and an equal number $y$ of firms that work in a traditional environment were selected, so $x=y$. The companies selected for the variable $x$ should contain an equal number of buyers and sellers; therefore, $x / 2=e$-commerce sellers and the remaining $x / 2=e-$ commerce buyers. Similarly, companies that belong to the section y should contain 
DOI: 10.14807/ijmp.v5i3.164

an equal number of buyers and sellers; therefore, $y / 2=$ traditional sellers and the remaining $y / 2=$ traditional buyers. Since the minimum acceptable number of cases for statistical analysis using SPSS is thirty, the numbers $x / 2$ and $y / 2$ should be equal, each with 30 .

This means $x / 2=y / 2=30$, so the minimum total number of e-commerce cases must be $60(x / 2+x / 2)$ and correspondingly the number of $y$ should be $60(y / 2+y / 2)$. As a result of the above model, the total sample involved 120 firms $x+y=120$ (Figure 3.1). (Figure 3.2) presents the methods and procedures of the second-stage quantitative research.

\begin{tabular}{|l|l|l|l|}
\hline \multicolumn{2}{|c|}{$\mathrm{x}$} & \multicolumn{2}{|c|}{$\mathrm{y}$} \\
\hline $\mathrm{x} / 2$ & $\mathrm{x} / 2$ & $\mathrm{y} / 2$ & $\mathrm{y} / 2$ \\
Sellers & Buyers & Sellers & Buyers \\
\hline $\mathrm{X}=$ e-commerce & $\mathrm{Y}=$ Traditional \\
\hline & \\
\hline & \\
\hline
\end{tabular}

Figure 3.1: Model of the logic research sample

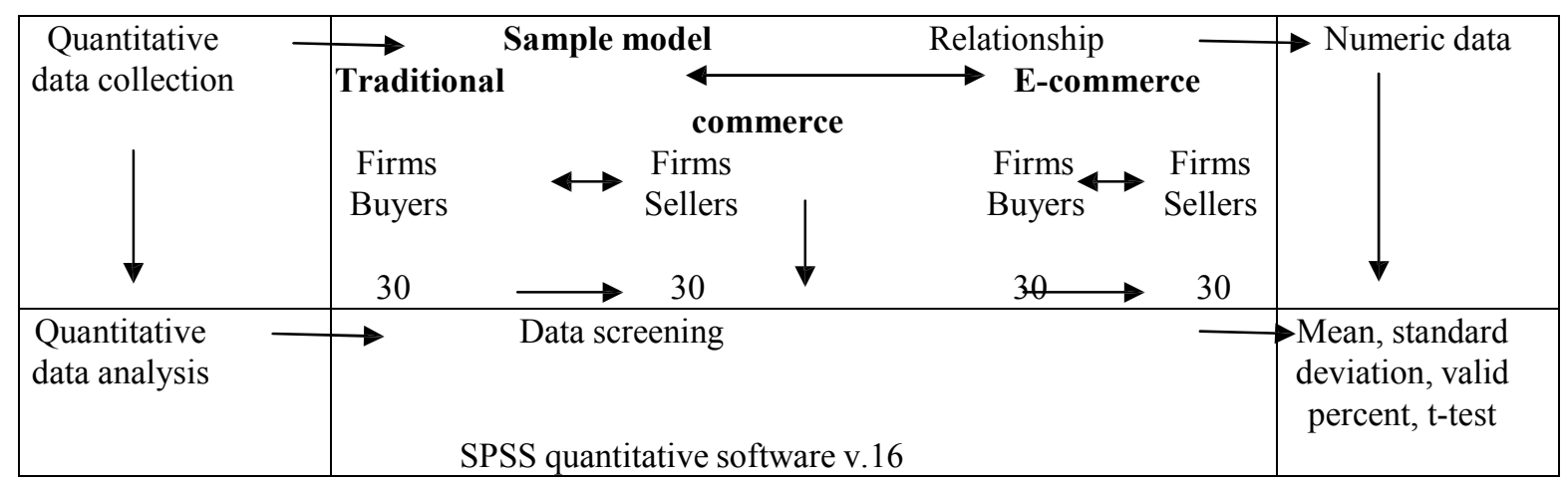

Figure 3.2: Methods and procedures of the quantitative research

For the 5-degree Likert scale questions to which the companies answered whether they use e-commerce or not, an independent sample t-test check was made in order to determine whether there is differentiation between the answers of the various "groups" of companies that are analyzed below. As we mentioned in relation to the research methodology, the 120 businesses are divided into 60 traditional and 60 e-commerce businesses. 
DOI: 10.14807/ijmp.v5i3.164

In each of these 2 groups there are 30 businesses that are buyers and 30 that are sellers. The means with typical standard deviations for all the questions to all the businesses and the sub-categories Traditional, E-commerce, Buyers traditional, Sellers traditional, Buyers e-commerce and Sellers e-commerce are presented in detail. Therefore the research examines the hypothesis below:

\section{H1:B2B relationships of Buyers traditional differ from Sellers traditional}

\section{H2:B2B relationships Buyers e-commerce differ from Sellers e-commerce}

H3: B2B relationships Sellers traditional differ from Sellers e-commerce

H4: B2B relationships Buyers traditional differ from Buyers e-commerce

Although the job titles of the respondents ranged from general manager to financial manager, purchasing/sales manager and marketing manager, all were mainly responsible for their MSFs purchasing or sales operations. In terms of profile, $20 \%$ of the respondent firms had fewer than 6 months of business experience with the supplier/buyer, 30\% varied between 6 and 12 months and the remaining $50 \%$ had more than 12 months of experience.

In this last group, $70 \%$ had more than 2 years of experience. This indicates that though the job description of the respondents' positions may be wide ranging, all appear to have significant knowledge about the specific purchasing or sales activities of the firm. However, although the respondents' profile suggests a high degree of confidence in the sample, we considered it important to test for possible nonresponse bias. By assessing the differences between the early and late respondents (ARMSTRONG; OVERTON, 1977), we found no significance differences.

According to the classification of the Industrial and Commercial Chamber of Piraeus for 2008 the population of medium sized firms in Greece was 2342 MSFs (Table 3.1). The sample of companies located in the greater area of Piraeus (Attica) was 1525 MSFs. The sample was formulated on the basis of 1525 MSFs. After an assessment of the sampling methods analyzed above, the systematic method was selected as most applicable for the present study. Each element had en equal probability of selection. 
DOI: 10.14807/ijmp.v5i3.164

The entire population ( $\mathrm{N}=1525 \mathrm{MSFs}$ ) was numbered and MSFs firms operate in traditional and e-commerce were 201 firms $13,2 \%$ of population. The rest of the population ( $\mathrm{N}=1324)$ was numbered and MSFs firms operate in traditional environment in 2004 were 1324 firms $86,8 \%$ of population. The questionnaire was addressed to the high level management (CEO, general director, sales managers, marketing managers). The number of employees was among 50 and 150 persons.

Table 3.1: Medium sized firms in Greece 2004

\begin{tabular}{|l|l|l|l|l|}
\hline Total MSFs in Greece & Commercial & Industrial & Services & A/O (Others) \\
\hline 2.342 & 534 & 984 & 742 & 82 \\
\hline MSFs in Greater area of Piraeus (Attica) & 483 & 579 & 49 \\
\hline 1.525 & 414 & 483 & & \\
\hline
\end{tabular}

The amount of time to complete the survey was restricted to 15-20 minutes. The use of sensitive questions was kept to a minimum. Finally, to establish trust with the respondents, the introduction of the survey explained why the study was important and a promise of confidentiality was made.

\subsection{The Validity and Reliability of responses}

In this research, social effect was minimized by emphasizing the confidentiality and the benefits of honest answers in the introduction part of the survey. Respondents were representative of the main industry and economic activities in the primary sector (25\%) and industrial sector $(75 \%)$. For this research, reliability was achieved, and the instrument was pretested and modified before being administered.

\subsection{Research Instrument}

Using a 5-degree Likert scale1, companies were asked to address the themes of relationship commitment, satisfaction with cooperation, trust, adaptation, and policies and practices (Table 4.1):

\footnotetext{
${ }^{1}$ Please rate your agreement with each of the following statements: Scale: $1=$ Strongly Disagree; $5=$ Strongly Agree 
Table 4.1: Questions for relationships

\begin{tabular}{|c|c|}
\hline $\begin{array}{l}\text { The questions for Relationship Commitment (adapted from } \\
\text { Anderson and Weitz, 1992) }\end{array}$ & Cronbach's $\alpha$ \\
\hline Our relationship with the supplier is a long-term partnership & .86 \\
\hline We would not drop the supplier because we like being associated with it & .69 \\
\hline $\begin{array}{l}\text { We want to remain as a customer of the supplier because we have pride } \\
\text { in being associated with a firm that carries a technological image }\end{array}$ & .87 \\
\hline \multicolumn{2}{|l|}{$\begin{array}{l}\text { The questions for Satisfaction with the cooperation (adapted from Cannon and } \\
\text { Homburg, 2001) }\end{array}$} \\
\hline Overall, we are satisfied with the supplier & .88 \\
\hline We are pleased with what the supplier does for us & .71 \\
\hline If we had to do it again, we would still choose to use the supplier & .88 \\
\hline \multicolumn{2}{|l|}{$\begin{array}{l}\text { The questions for Trust (adapted from Morgan and Hunt, } \\
\text { 1994) }\end{array}$} \\
\hline $\begin{array}{l}\text { In our relationship, the supplier/buyer is someone to whom I give my } \\
\text { confidence }\end{array}$ & .91 \\
\hline In our relationship, the supplier/buyer is someone who has high integrity & .91 \\
\hline In our relationship, the supplier/buyer is someone who Is perfectly truthful & .91 \\
\hline $\begin{array}{l}\text { In our relationship, the supplier/buyer is someone who gives us reliable } \\
\text { information and advice }\end{array}$ & .91 \\
\hline \multicolumn{2}{|l|}{ The questions for Policies and Practices (adapted from Heide and John, 1990) } \\
\hline The supplier/buyer has policies that show respect for the customer & .81 \\
\hline The supplier/buyer has practices that make solving problems easy & .82 \\
\hline The supplier/buyer solves my firm's problems quickly & .61 \\
\hline \multicolumn{2}{|l|}{ To accomplish its own objectives, sometimes supplier/buyer... } \\
\hline Promises to do things without doing them later & .90 \\
\hline Fails to provide us with the support that they are obliged to & .70 \\
\hline
\end{tabular}

An independent sample t-test check was made in order to determine whether there is differentiation between the answers of the various "groups" of companies that are analyzed below. For each of the four groups of 30 businesses, the means and standard deviations for all the questions to all the businesses 'Traditional' and 'Ecommerce', and the sub-categories 'Buyers traditional', 'Sellers traditional', 'Buyers ecommerce' and 'Sellers e-commerce', are presented in detail.

\section{RESEARCH FINDINGS}

\subsection{Satisfaction with cooperation/relationship}

The questionnaire refers to "satisfaction with cooperation", "relational commitment", "trust" and "adaptation" concerning the activities built amongst businesses in relation to customers/suppliers. Companies indicated on a scale from one (1) to five (5) whether they agreed or disagreed with each statement.

In regard to "satisfaction with cooperation", Table 4.2 presents in detail the means with standard deviations for all the questions to all the businesses and the 
DOI: 10.14807/ijmp.v5i3.164

sub-categories Traditional and E-commerce, and Buyers traditional, Sellers traditional, Buyers e-commerce and Sellers e-commerce.

The only exception lies with the statement "We work closely with our customers/suppliers with regard to the quality of products/services" where traditional and e-commerce firms present lower averages $(3,40)$ in this statement. Nearly $50 \%$ of the companies asked strongly agreed with this statement. It is also worth noting that nearly $60 \%$ agreed with the statement "We work closely with our customers/suppliers with regard to stock retention"; that was the largest acceptance percentage that occurred for any single statement.

Table 4.2: Satisfaction with cooperation (traditional-e-commerce, traditional sellersbuyers, e-commerce sellers-buyers) Sample size $(\mathrm{N}=120)$

\begin{tabular}{|l|c|c|c|c|c|c|}
\hline & \multicolumn{2}{|c|}{$\begin{array}{c}\text { Traditional-E- } \\
\text { commerce }\end{array}$} & \multicolumn{2}{c|}{$\begin{array}{c}\text { Traditional } \\
\text { Sellers-Buyers }\end{array}$} & \multicolumn{2}{|c|}{$\begin{array}{c}\text { E-commerce } \\
\text { Sellers- } \\
\text { Buyers }\end{array}$} \\
\hline Variables & Mean & St. Dev. & Mean & St. Dev. & Mean & St. Dev. \\
\hline $\begin{array}{l}\text { We cooperate to a great } \\
\text { extent with our } \\
\text { clients/suppliers as regards }\end{array}$ & 3.80 & 3.80 & 3.95 & 0.680 & 3.64 & 0.826 \\
\hline $\begin{array}{l}\text { We cooperate to a great } \\
\text { extent with our } \\
\text { clients/suppliers as regards } \\
\text { communication and }\end{array}$ & 3.73 & 0.769 & 3.74 & 0.768 & 3.72 & 0.933 \\
\hline $\begin{array}{l}\text { We cooperate to a great extent } \\
\text { with our clients/suppliers as } \\
\text { regards the planning of }\end{array}$ & 3.73 & 3.73 & 3.41 & 0.918 & 3.40 & 0.990 \\
\hline $\begin{array}{l}\text { We cooperate to a great } \\
\text { extent with our } \\
\text { clients/suppliers as regards } \\
\text { the forecasting and }\end{array}$ & 3.92 & 0.851 & 4.03 & 0.946 & 3.81 & 0.937 \\
\hline $\begin{array}{l}\text { We cooperate to a great } \\
\text { extent with our } \\
\text { clients/suppliers as regards } \\
\text { the quality of the }\end{array}$ & 3.41 & 3.41 & 4.26 & 1.001 & 4.34 & 0.637 \\
\hline
\end{tabular}

\subsection{Relational commitment}

The next section considers "relational commitment" (Table 4.3). It is noted here that the most frequent response from the questionnaire participants is that they strongly agree with the statements offered. This indicates that the statements describing relational commitment reflect the views of the majority of companies. 
DOI: 10.14807/ijmp.v5i3.164

Table 4.2:Satisfaction with cooperation (traditional-e-commerce, traditional sellersbuyers, e-commerce sellers-buyers) Sample size ( $N=120)$

\begin{tabular}{|l|c|c|c|c|c|c|}
\hline & \multicolumn{2}{|c|}{$\begin{array}{c}\text { Traditional-E- } \\
\text { commerce }\end{array}$} & \multicolumn{2}{c|}{$\begin{array}{c}\text { Traditional } \\
\text { Sellers-Buyers }\end{array}$} & \multicolumn{2}{c|}{$\begin{array}{c}\text { E-commerce Sellers- } \\
\text { Buyers }\end{array}$} \\
\hline Variables & $\begin{array}{l}\text { Mean } \\
\text { Score }\end{array}$ & St. Dev. & $\begin{array}{l}\text { Mean } \\
\text { Score }\end{array}$ & St. Dev. & $\begin{array}{l}\text { Mean } \\
\text { Score }\end{array}$ & St. Dev. \\
\hline $\begin{array}{l}\text { We hope to work with our } \\
\text { customers/suppliers for a } \\
\text { long time }\end{array}$ & 4.51 & 0.582 & 4.53 & 0.599 & 4.42 & 0.680 \\
\hline $\begin{array}{l}\text { We have a strong sense of } \\
\text { commitment to our } \\
\text { customers/suppliers }\end{array}$ & 4.36 & 0.703 & 4.29 & 0.726 & 4.34 & 0.863 \\
\hline $\begin{array}{l}\text { Our relationship with our } \\
\text { customers/suppliers is based } \\
\text { on a long-term view }\end{array}$ & 4.42 & 0.746 & 4.50 & 0.600 & 4.24 & 0.953 \\
\hline $\begin{array}{l}\text { We look forward to remaining } \\
\text { partners with our } \\
\text { customer/supplier and we are } \\
\text { proud to work with a } \\
\text { technologically acute } \\
\text { business }\end{array}$ & 4.26 & 0.824 & 4.29 & 0.676 & 4.27 & 0.639 \\
\hline
\end{tabular}

The results support the accepted view, identified in the literature review above, that commitment is a critical factor in industrial exchanges between companies. The levels of commitment are found to be positively related to the level of the propensity to maintain the relationships for a long time. As a whole, the results reinforce the importance of long-term commitment as an antecedent of behavioral intentions concerning the development of B2B e- relationships. In particular, commitment and trust are the main mediators in the model proposed, following the Morgan and Hunt (1994) model.

\subsection{Trust}

As far as "trust" is concerned, it is apparent from the response frequencies (Table 4.4) that the majority of companies agree with the statements addressing issues of trust amongst businesses. It is worth noting that over $70 \%$ of the companies claim that the customer/supplier trusts their business when responding to the following question: "How would you grade the level of trust that your company maintains in its relationship with its customers/suppliers based on both previous and 
DOI: 10.14807/ijmp.v5i3.164

current experience?" Over $50 \%$ of the companies agree with the rest of the statements made in this section of the questionnaire.

Table 4.4: Trust (traditional-e-commerce, traditional sellers-buyers, e-commerce sellers- buyers) Sample size $(N=120)$

\begin{tabular}{|c|c|c|c|c|c|c|}
\hline \multirow[b]{2}{*}{ Variables } & \multicolumn{2}{|c|}{$\begin{array}{l}\text { Traditional- } \\
\text { E- } \\
\text { commerce }\end{array}$} & \multicolumn{2}{|c|}{$\begin{array}{l}\text { Traditiona } \\
\text { I } \\
\text { Sellers- } \\
\text { Buyers }\end{array}$} & \multicolumn{2}{|c|}{$\begin{array}{l}\text { E-commerce } \\
\text { Sellers- Buyers }\end{array}$} \\
\hline & $\begin{array}{l}\text { Mean } \\
\text { Score }\end{array}$ & St. Dev. & $\begin{array}{l}\text { Mean } \\
\text { Score }\end{array}$ & St. Dev & $\begin{array}{l}\text { Mean } \\
\text { Score }\end{array}$ & St. Dev. \\
\hline $\begin{array}{l}\text { Our customers/suppliers are } \\
\text { consistent and honest with } \\
\text { their obligations }\end{array}$ & 4.14 & 0.742 & 3.54 & 0.734 & 3.69 & 0.836 \\
\hline $\begin{array}{l}\text { We trust our } \\
\text { customers/suppliers }\end{array}$ & 3.88 & 0.659 & 3.84 & 0.670 & 3.68 & 0.730 \\
\hline $\begin{array}{l}\text { Our relationships with our } \\
\text { customers/suppliers are } \\
\text { completely trustworthy }\end{array}$ & 3.61 & 0.732 & 4.00 & 0.816 & 3.92 & 0.651 \\
\hline $\begin{array}{l}\text { Our customers/suppliers } \\
\text { provide us with reliable } \\
\text { information and advisory } \\
\text { services }\end{array}$ & 3.60 & 0.743 & 3.50 & 0.628 & 3.93 & 0.583 \\
\hline $\begin{array}{l}\text { How would you grade the } \\
\text { level of trust that your } \\
\text { company maintains in its } \\
\text { relationship with its } \\
\text { customers/suppliers based } \\
\text { on both previous and current } \\
\text { experience? }\end{array}$ & 3.81 & 0.556 & 3.69 & 0.503 & 4.12 & 0.613 \\
\hline
\end{tabular}

An e-commerce relationship occurs when there is a situation of high partner trust and high technology trust. Because the firm trusts the partner and the technology, it will seek to extend the benefits provided by the e-commerce solutions. Their discussions focus on identifying future investments and opportunities for sharing and realizing joint gains. The firm may reveal future competitive intentions and share additional information. Previous positive relationships are easily transferable across firms and enhance the credibility between firms.

Positive repeated behaviors of partners increase the focal firm's satisfaction and enable goodwill partner trust to develop. Anderson and Narus (1994) found a close connection between cooperation and trust. They suggested an iterative 
DOI: 10.14807/ijmp.v5i3.164

process or virtuous circle in that cooperation leads to trust, which in turn leads to a greater willingness to cooperate in the future, which then generates trust and so on.

\subsection{Adaptation}

In the section referring to "adaptation", the frequencies of the responses received suggest that the majority of companies agree with the statements presented to them relating to this theme (Table 4.5). It is worth noting that over $60 \%$ of the participants answered affirmatively to the following statement: "Our production system is adapted to the requirements of our customers/suppliers". It can be seen that the means of responses do not differ for these questions. Inter-firm adaptation seems to help to build a better competitive position through a stronger customersupplier relationship.

Table 4.5: Adaptation (traditional-e-commerce, traditional sellers-buyers, ecommerce sellers-buyers) Sample size $(\mathrm{N}=120)$

\begin{tabular}{|l|l|l|l|l|l|l|}
\hline & \multicolumn{2}{|c|}{$\begin{array}{l}\text { Traditional- } \\
\text { E-commerce }\end{array}$} & \multicolumn{2}{|c|}{$\begin{array}{c}\text { Traditional } \\
\text { Sellers- } \\
\text { Buyers }\end{array}$} & \multicolumn{2}{|c|}{$\begin{array}{c}\text { E-commerce } \\
\text { Sellers- } \\
\text { Buyers }\end{array}$} \\
\hline Variables & $\begin{array}{l}\text { Mean } \\
\text { Score }\end{array}$ & $\begin{array}{l}\text { St. } \\
\text { Dev. }\end{array}$ & $\begin{array}{l}\text { Mean } \\
\text { Score }\end{array}$ & $\begin{array}{l}\text { St. } \\
\text { Dev. }\end{array}$ & $\begin{array}{l}\text { Mean } \\
\text { Score }\end{array}$ & $\begin{array}{l}\text { St. } \\
\text { Dev. }\end{array}$ \\
\hline $\begin{array}{l}\text { Our production system is } \\
\text { adapted to the requirements } \\
\text { of our customers/suppliers }\end{array}$ & 4.14 & 0.598 & 4.16 & 0.586 & 4.28 & 0.825 \\
\hline $\begin{array}{l}\text { We have made significant } \\
\text { investments in equipment that } \\
\text { is linked to our relationships } \\
\text { with our customers/suppliers }\end{array}$ & 4.21 & 0.832 & 4.07 & 4.14 & 0.840 & 3.87 \\
\hline $\begin{array}{l}\text { Transactions with these } \\
\text { customers/suppliers require } \\
\text { specialized technology }\end{array}$ & 3.79 & 0.928 & 3.71 & 0.889 & 3.72 & 0.559 \\
\hline
\end{tabular}

\subsection{Relationship policies and practices}

This leads on to how policies and practices are evolved and the extent to which there have been changes (if any) once companies' cooperation has been achieved through e- commerce. As shown in (Table 4.6), the companies that participated in the research agreed to a certain extent with the first three statements, and the means do not differ between different groups for these questions. The inter- 
DOI: 10.14807/ijmp.v5i3.164

firm adaptation helps to build a better competitive position through a stronger customer-supplier relationship.

Table 4.6: Relationship policies and practices (traditional-e-commerce, traditional sellers-buyers, e-commerce sellers-buyers) Sample size ( $N=120)$

\begin{tabular}{|l|c|c|c|c|c|c|}
\hline & \multicolumn{2}{|c|}{$\begin{array}{c}\text { Traditional- } \\
\text { E- } \\
\text { commerce }\end{array}$} & \multicolumn{2}{|c|}{$\begin{array}{c}\text { Tradition } \\
\text { al Sellers- } \\
\text { Buyers }\end{array}$} & \multicolumn{2}{|c|}{$\begin{array}{c}\text { E-commerce } \\
\text { Sellers-Buyers }\end{array}$} \\
\hline Variables & $\begin{array}{c}\text { Mean } \\
\text { Score }\end{array}$ & St. Dev. & $\begin{array}{c}\text { MeanS } \\
\text { core }\end{array}$ & St. Dev. & $\begin{array}{c}\text { Mean } \\
\text { Score }\end{array}$ & St. Dev. \\
\hline $\begin{array}{l}\text { Our suppliers/customers have } \\
\text { practices that make solving } \\
\text { problems easy }\end{array}$ & 3.61 & 0.643 & 3.50 & 0.701 & 3.38 & 0.671 \\
\hline $\begin{array}{l}\text { Our suppliers/clients solve the } \\
\text { problems of our business } \\
\text { quickly }\end{array}$ & 3.25 & 0.764 & 3.13 & 0.833 & 2.63 & 0.723 \\
\hline $\begin{array}{l}\text { The supplier/client fails to } \\
\text { provide the support which he } \\
\text { is obliged to }\end{array}$ & 2.67 & 0.780 & 2.71 & 0.838 & 4.49 & 0.569 \\
\hline
\end{tabular}

Table 4.7 contains the t-test check for Buyers traditional differ Sellers traditional. The statistical hypothesis that we want to check is whether the mean values of the two company groups for each factor are the same. We define a trust level of $5 \%$. If the significance values are lower than 0.05 , the means have an important statistical difference. We can see that the means differ for the questions regarding "Pressure from competition on the company", "Clients asking for lower product prices" and "Pressure to lower the operating cost"; they have a significance $<0.05$ and therefore the means for these questions show an important statistical difference between Buyers traditional and Sellers traditional.

B2B e-commerce seems to be driven by global forces. We find that for B2B ecommerce, competitive forces are the greatest driver of adoption. Global competition and participation in production networks create strong pressure to adopt e-marketing and logistics practices through e- commerce. The global competitive pressure is driving greater convergence in business practices through the integration of production networks and supply chains. 
DOI: 10.14807/ijmp.v5i3.164

Competitive pressure seems to be the strongest driver of e-commerce in most of the responses. The globalization of business and competition pressures firms to adopt new technology to streamline their processes and expand their markets. Market liberalization and deregulation facilitate the internationalization of businesses through opening the economy to greater foreign as well as domestic competition and to global suppliers and customers. This in turn creates pressure on local companies to adopt e-commerce to remain competitive. In the process, business practices become more standardized across borders.

The key inhibitors of $\mathrm{B} 2 \mathrm{~B}$ e-commerce are the business environment and culture, national culture and political institutions. The organizational readiness to embrace e- commerce is often low due to business cultures that do not support innovation and the use of new technology (chapter 8).

Table 4.7: Independent samples test (a) Sample size ( $\mathrm{N}=120)$

\begin{tabular}{|c|c|c|c|c|c|c|c|c|c|c|c|c|c|c|c|}
\hline & \multicolumn{3}{|c|}{$\begin{array}{l}\text { t-test } \\
\text { Buyers traditional } \\
\text { Sellers traditional }\end{array}$} & \multicolumn{3}{|c|}{$\begin{array}{l}\text { t-test } \\
\text { Buyers e-commerce } \\
\text { Sellers e-commerce }\end{array}$} & \multicolumn{3}{|c|}{$\begin{array}{l}\text { t-test check for } \\
\text { Sellers traditional } \\
\text { vs. Sellers e- } \\
\text { commerce }\end{array}$} & \multicolumn{3}{|c|}{$\begin{array}{l}\text { t-test check for } \\
\text { Buyers traditional vs. } \\
\text { Buyers e-commerce }\end{array}$} & \multicolumn{3}{|c|}{$\begin{array}{l}\text { t-test check for } \\
\text { Buyers-sellers } \\
\text { traditional vs. Buyers- } \\
\text { sellers e-commerce }\end{array}$} \\
\hline & $\begin{array}{l}\text { t-test fo } \\
\text { Means }\end{array}$ & or Equa & ality of & $\begin{array}{l}\text { t-testfo } \\
\text { Means }\end{array}$ & Equalit & & $\begin{array}{l}\text { t-testfor } \\
\text { Means }\end{array}$ & Equalits & & $\begin{array}{l}\text { t-test fo } \\
\text { Means }\end{array}$ & Equality & & \begin{tabular}{|l} 
t-testfo \\
Means
\end{tabular} & I Equality & \\
\hline Variables & $\mathrm{t}$ & $\begin{array}{l}d \\
f\end{array}$ & \begin{tabular}{|l} 
Sig. \\
$(2-$ \\
tailed $)$
\end{tabular} & $\mathrm{t}$ & df & \begin{tabular}{|l|} 
Sig. \\
$(2-$ \\
taile \\
d) \\
\end{tabular} & $\mathrm{t}$ & $\mathrm{df}$ & \begin{tabular}{|l|} 
Sig. \\
$(2-$ \\
tailed $)$
\end{tabular} & $\mathrm{t}$ & df & $\begin{array}{l}\text { Sig. } \\
(2- \\
\text { taile } \\
\text { d) }\end{array}$ & $\mathrm{t}$ & $\mathrm{df}$ & \begin{tabular}{|c|} 
Sig. \\
$(2-$ \\
tailed)
\end{tabular} \\
\hline $\begin{array}{l}\text { Globalization } \\
\text { and market } \\
\text { deregulation }\end{array}$ & $-0,413$ & 57 & 0.681 & -0.823 & 49.866 & 0.414 & 0.018 & 56.495 & 0.986 & -0.437 & 54.336 & 0.664 & -0.232 & 114.970 & 0.817 \\
\hline $\begin{array}{l}\text { Pressure } \\
\text { from } \\
\text { competition } \\
\text { on the }\end{array}$ & -2.397 & 57.839 & 0.020 & 0.408 & 48.409 & 0.685 & $|-1.506|$ & 57.451 & $\mid 0.137$ & 1.183 & 49.704 & 0.242 & -0.062 & 114.624 & 0.951 \\
\hline $\begin{array}{l}\text { Clients asking } \\
\text { for lower } \\
\text { product prices }\end{array}$ & $-3,026$ & 52.382 & $\mid 0.004$ & $-0.963 \mid$ & 55.938 & 0.340 & $-0.474 \mid$ & 56.312 & 0.637 & 1.880 & 55.049 & 0.065 & 0.808 & 114.585 & 0.421 \\
\hline $\begin{array}{l}\text { Pressure to } \\
\text { lower the } \\
\text { operating cost }\end{array}$ & -2.380 & 51.661 & $|0.021|$ & -0.342 & 55.969 & 0.734 & -0.872 & 55.191 & $\mid 0.387$ & 1.337 & 54.617 & 0.187 & 0.178 & 114.554 & 0.859 \\
\hline $\begin{array}{l}\text { Pressure from } \\
\text { clients/suppliers } \\
\text { who have } \\
\text { adopted e- } \\
\text { commerce }\end{array}$ & -1.318 & 50.974 & 0.193 & 0.301 & 55.934 & 0.765 & $|-0.334|$ & 57.972 & 0.740 & 1.313 & |49.424 & 0.195 & 0.565 & 113.412 & 0.573 \\
\hline $\begin{array}{l}\text { Pressure for a } \\
\text { better stock } \\
\text { control system }\end{array}$ & -0.269 & 58 & 0.789 & 0.647 & 44.006 & 0.521 & $|-0.103|$ & 49.137 & 0.918 & 1.017 & 54.603 & 0.314 & 0.484 & 108.887 & 0.629 \\
\hline
\end{tabular}

Table 4.8 contains the t-test check for Sellers traditional vs. Sellers ecommerce. The statistical hypothesis that we aim to check is whether the mean values of the two company groups for each factor are equal. We define a trust level of $5 \%$. Wherever the significance values are lower than 0.05 , the means have an important statistical difference. We can see that the means differ for the statement 
DOI: 10.14807/ijmp.v5i3.164

"We cooperate to a great extent with our clients/suppliers as regards the stock retention" because the significance level is $<0.05$ and therefore the means for those questions differ considerably among the Sellers traditional and the Sellers ecommerce as well as between the Buyers-sellers traditional and the Buyers- sellers e-commerce. Similarly, the means differ for the statement "our relations with our suppliers/clients are very reliable".

Table 4.8: Satisfaction with cooperation independent samples test (a) Sample size $(\mathrm{N}=120)$

\begin{tabular}{|c|c|c|c|c|c|c|c|c|c|c|c|c|c|c|c|}
\hline & \multirow{2}{*}{\multicolumn{3}{|c|}{$\begin{array}{l}\text { t-test } \\
\text { Buyers traditional } \\
\text { Sellers traditional } \\
\text { t-test for Equality of } \\
\text { Means }\end{array}$}} & \multicolumn{3}{|c|}{$\begin{array}{l}\text { t-test } \\
\text { Buyers e-commerce } \\
\text { Sellers e-commerce }\end{array}$} & \multicolumn{3}{|c|}{$\begin{array}{l}\text { t-test check for } \\
\text { Sellers traditiona/ vs. } \\
\text { Sellers e-commerce }\end{array}$} & \multicolumn{3}{|c|}{$\begin{array}{l}\text { t-test check for Buyers } \\
\text { traditiona/ vs. } \\
\text { Buyers e-commerse }\end{array}$} & \multicolumn{3}{|c|}{$\begin{array}{l}\text { t-test check for } \\
\text { Buvers-sellers traditional } \\
\text { vs. Buyers-sellers e- } \\
\text { commerce }\end{array}$} \\
\hline & & & & $\begin{array}{l}\text { t-test fo } \\
\text { Means }\end{array}$ & Equalit & & $\begin{array}{l}\text { t-test fo } \\
\text { Means }\end{array}$ & I Equality & & $\begin{array}{l}\text { t-test fo } \\
\text { Mesns }\end{array}$ & Equalit & & $\begin{array}{l}\text { t-test fo } \\
\text { Means }\end{array}$ & or Equality & \\
\hline Variables & $t$ & $\begin{array}{l}d \\
f\end{array}$ & $\begin{array}{l}\text { Sig. (2- } \\
\text { taile d) }\end{array}$ & $t$ & $\begin{array}{l}d \\
f\end{array}$ & \begin{tabular}{|c|} 
Sig. \\
$(2-$ \\
tailed $)$
\end{tabular} & $t$ & $\begin{array}{l}d \\
f\end{array}$ & $\begin{array}{l}\text { Sig. (2- } \\
\text { taile d) }\end{array}$ & $t$ & $d f$ & $\begin{array}{l}\text { Sig. } \\
(2- \\
\text { tailed })\end{array}$ & $\mathrm{t}$ & $d f$ & \begin{tabular}{|c|} 
Sig. \\
$(2-$ \\
tgiled $)$
\end{tabular} \\
\hline $\begin{array}{l}\text { We cooperate to a great } \\
\text { extent with our } \\
\text { clients/suppliers as } \\
\text { regards the stock } \\
\text { retention }\end{array}$ & 0.200 & 56.767 & 0.842 & -1.819 & 52.550 & 0.075 & 2.424 & $53.25 \mathrm{~d}$ & 0.019 & 0,556 & 56.923 & 0.580 & 2.191 & 111.917 & 0.031 \\
\hline $\begin{array}{l}\text { We cooperate to a great } \\
\text { extent with our } \\
\text { clients/suppliers as } \\
\text { regards communication } \\
\text { and technology }\end{array}$ & -0.126 & 54.478 & 0.900 & -1.775 & 44.761 & 0.083 & 0.892 & 47.35 月 & 0.377 & -0.931 & 53.562 & 0.356 & 0.080 & $|109.667|$ & 0.937 \\
\hline $\begin{array}{l}\text { We cooperate to a great } \\
\text { extent with our } \\
\text { clients/suppliers as } \\
\text { regards the planning of } \\
\text { processes }\end{array}$ & 0.569 & 55.823 & 0.572 & -1.474 & 51.592 & 0.147 & 1.015 & $54.62 €$ & 0.315 & -1.067 & 55.602 & 0.291 & 0.097 & 113.360 & 0.923 \\
\hline $\begin{array}{l}\text { Our relations with our } \\
\text { suppliers/clients are } \\
\text { very reliable }\end{array}$ & 0.964 & 55.386 & 0.339 & -0.440 & 56.949 & 0.662 & 1.131 & 55.934 & 0.263 & -1.646 & 54.373 & 0.105 & -1.999 & 107.849 & 0.048 \\
\hline $\begin{array}{l}\text { We cooperate to a grest } \\
\text { extent with our } \\
\text { clients/suppliers as } \\
\text { regards the quality of the } \\
\text { products }\end{array}$ & 0.200 & 51.871 & 0.842 & -0.409 & 55.800 & 0.684 & -0.126 & 52.083 & 0.901 & -0.603 & 44.599 & 0.549 & -0.553 & 96.627 & 0.581 \\
\hline $\begin{array}{l}\text { We cooperate to a grest } \\
\text { extent with our } \\
\text { clients/suppliers as } \\
\text { regards the design of the } \\
\text { product }\end{array}$ & -0.312 & $53.97 \mathrm{~g}$ & 0.756 & 0.458 & 53.384 & 0.649 & -0.227 & $53.00 \mathrm{~d}$ & 0.821 & 0.564 & $\begin{array}{c}56.54 \\
7\end{array}$ & 0.575 & 0.228 & 111.780 & 0.820 \\
\hline
\end{tabular}

\section{CONCLUSION}

The general finding of this thesis is that enterprises active, in both physical markets as well as in electronic ones, use the internet to replace their existing strategy rather than as an opportunity to establish a new strategy. We confirmed that organizations tend to respond defensively rather than strategically to the challenge of the electronic market.

In e-marketing, the management of B2B e-relationships seems to matter, as cooperation with clients/suppliers impacts strongly as regards the quality of the products and the stock retention compared with traditional commerce. This is 
DOI: 10.14807/ijmp.v5i3.164

because e-marketing can contribute in terms of the speed of the implementation of Just-In-Time (JIT) processes and trades, thus keeping buyers in stock at lower levels. A main characteristic of e-commerce is also standardization, meaning the buyer can search for and find a specific product.

As regards cooperation among buyers and sellers in the planning of processes, communication and the forecasting and programming of production are important to the same extent. Nevertheless, some important differences emerged in their cooperation in e-commerce; the research revealed that sellers behave differently to buyers. This means that sellers are engaged more in cooperation with buyers in the exchange of information and communication through technological means and in stock retention, and generally their behavior is reliable.

As regards cooperation among buyers and sellers in the planning of processes, communication and the forecasting and programming of the production are important to the same extent. Some important differences emerged in their cooperation in e- commerce, as we found that sellers behave differently to buyers. This means that sellers are engaged more in cooperation with buyers in the exchange of information and communication through technological means and in stock retention, and generally their behavior is reliable.

All businesses want to have relational commitment with their partners for a long time and even believe that this commitment will lead to benefits if one of the partners is working with a technologically acute business. We also found that suppliers engaged in electronic commerce are more committed and oriented in a long-term relationship than buyers are. The confidence in relations between firms is an important factor in the development and establishment of their relationships.

Therefore, businesses operating in an environment of e-commerce consider it to be a crucial factor. This includes being consistent and honest in their obligations and the exchange of reliable and trustworthy information and advisory services. Ecommerce sellers must differentiate themselves from their partners in e-commerce. It is argued that the level of trust that the company maintains in its relationship with its customers/suppliers is based on both previous and current experience. This suggests it is very important for companies to collaborate in an e-commerce environment. 
DOI: 10.14807/ijmp.v5i3.164

We argue that the level of trust that the company maintains in its relationship with its customers/suppliers is based on both previous and current experience. This statement confirms that it is very important for companies to collaborate in an ecommerce environment. The level of trust that governs their relationships should be promoted in order to establish an electronic relationship.

Both the firm's ability to allocate resources and to adapt their business processes to meet the individual needs of partners forms a special relationship, which has a good chance of being maintained in the long-term when operating in an environment of e-commerce. In our research, all the companies seem to have accepted both these aspects and considered it to be important for their adaptation to customer requirements and equipment investment in order to satisfy their needs. However, some seem to be reluctant to adapt to the required specialized technologies, but this is reasonable if one considers that Greek companies are still under-developed in terms of investment in new technologies. Therefore, companies do not seem to differ on the early stage because of e-commerce.

Regarding the practices and procedures followed by companies to enhance their relationships, it seems that B2B companies operating in traditional environments have a certain number of appropriate practices and flexibility to make quick decisions to solve problems easily and quickly when they arise. On the other hand, companies operating in electronic environments seem to carry out the obligations they have undertaken.

The practice of problem solving appears to be entirely appropriate and there is a lag in immediate decisions when a problem occurs. In general, the policies and practices of B2B companies in problem solving seem to present no difficulty in general, except for traditional businesses that are happy after their partners keep their obligations. This seems reasonable since, in traditional trade, relations are faceto-face and subject to negotiation.

\section{MANAGERIAL IMPLICATIONS}

The research allows the idea to be suggested and reinforced that the B2B relationship process needs to be regarded by academics and practitioners as a longterm rewarding process, even in an electronic and real time environment. The main 
DOI: 10.14807/ijmp.v5i3.164

determinants of customer cooperation rely mainly on trust and commitment. Commitment development requires the previous achievement of trust.

As a starting point, this reality enhances the importance of establishing adequate marketing activities that lead to customer trust, such as relationship policies and practices, communication and meaningful information exchange facilities, and the fulfillment of all forwarded promises, not forgetting that suppliers need to pay special attention to their pricing policies. In the electronic market context, e-marketing is required to perform new roles, such as a buyer support service that is associated with trust, commitment and cooperation.

Suppliers should also be aware that as the relationship process develops, customers make significant investments in learning about a firm's products and business practices as well as in supporting infrastructure that is only available from specific firms. These investments represent very good reasons for buyers' commitment development (resulting in higher product purchases and meaningful information exchange) and a stronger cooperative long-term relationship with the supplier.

\section{LIMITATIONS AND FUTURE RESEARCH}

There are some limitations to consider regarding the results of this research. First, buyers and sellers' views are offered as a starting point to understanding the determinants of B2B relationships in an e-business environment. The research relies on the responses of the buyers and sellers only from medium-sized firms in Greece, providing an incomplete view of the relationships. Since buyer-supplier relationship research in the electronic market context is still at an early stage and yet has been heralded from two decades (MORGAN; HUNT, 1994), these views are presented as a preliminary to understanding how they can develop and adapt an e-marketing strategy as well generate trust and commitment in their relationships (JAP; GANESAN, 2000).

Nevertheless, future research is strongly encouraged on a bigger sample, separately assessing sellers' and buyers' views. In particular, a survey from a wider area in Greece would explore whether non-capital region businesses are different and whether the financial crisis and austerity cuts have impacted on the research findings. A third potential area to explore generalizability would be to include the 
DOI: 10.14807/ijmp.v5i3.164

service sector. It is hoped that by shedding light on the use of new information and communication technologies, this study will trigger further works on the improvement of $\mathrm{B} 2 \mathrm{~B}$ relationship theory and practices in a B2B e-context.

\section{REFERENCES}

ALBRECHT, C.; DEAN, D.; HANSEN, J. (2005). Marketplace and Technology Standards for B2B E-commerce: Progress, Challenges, and the State of the Art. Information and Management, v. 42 n. 3, p. 865-875.

ANDERSON, E.; WEITZ, B. (1992) The use of pledges to build and sustain commitment in distribution channels, Journal of Marketing Research, v. 29, n. 1, p. 18-34.

ANDERSON, E. W.; FORNELL, C.; LEHMANN, D. R. (1994) Customer satisfaction, market share and profitability: Findings from Sweden, Journal of Marketing, v. 58, n. July, p. 53-66.

ANDERSON, J. C.; NARUS, J. A. (1994) A model of the distributor's perspective of distributor- manufacturer working relationships, Journal of Marketing, v. 48, n. 4, p. 62-74.

BARRY M.; DION P.; JOHNSON W. (2008). A Cross-cultural Examination of Relationship Strength in B2B Services. Journal of Services Marketing, v. 22, n. 2, p. 114-135.

BELL, J. (1995) The internationalisation of small computer software firms: A further challenge to 'stage' theories', European Journal of Marketing, v. 29, n. 8, p. 60-75.

BERRY, L.; PARASURAMAN, A. (1991) Marketing Services: Competing Through Quality. New York, N.Y.: Free Press.

BERRY, L. L. (1983) Relationship marketing, Emerging Perspectives on Services Marketing, American Marketing Association, Chicago.

BOWMAN, D.; NARAYANDAS, D. (2004) Linking customer management effort to customer profitability in business markets, Journal of Marketing Research, v. 41, November, p. 433.

CANNON, J.; HOMBURG, C (2001) Buyers-supplier relationships and customer firm costs, Journal of Marketing, v. 65, n. 1, p. 29-44.

CASTELLS, M. (2005) Global governance and global politics, PS: Political Science and Politics, v. 38, n. 1, p. 9-16.

DEIGHTON, J (1997) Commentary on 'exploring the implications of the for consumer marketing, Journal of Academy of Marketing Science, v. 25, n. 4, p. 347-353.

DEMARTINO, B.; KUMARAN, D.; SEYMOUR, B.; DOLAN, R. J. (2006) Frames, Biases, and Rational Decision-making in the Human Brain. Science, n. 313, p. 684687.

DONEY, P. M.; CANNON, J. P. (1997) An examination of the nature of trust in buyerseller relationships, Journal of Marketing, v. 61, n. 2, p. 35-51.

DUGGAN, M.; DEVENERY, J. (2000) How to make Internet marketing simple, Communication World, v. 17, n. 4, p. 58-61. 
DWYER, F. R.; SCHURR, P. H.; OH, S. (1987) Developing buyer-seller relationships, Journal of Marketing, v. 51, n. 2, p. 11-27.

EID, R.; TRUEMAN, M.; AHMED, A. M. (2006) B2B International Internet Marketing: A Benchmarking Exercise. Benchmarking: An International Journal, v. 13 n. 1/2, p. 200-213.

FORRESTER RESEARCH (2010) Trends 2010: e-commerce platform and technology, March.

GANESAN, S. (1994) Determinants of long-term orientation in buyer-seller relationships, Journal of Marketing, v. 58 n. 2, p. 1-19.

GARBARINO, E.; JOHNSON M. S. (1999) The Different Roles of Satisfaction, Trust, and Commitment in Customer Relationships. Journal of Marketing v. 63 (April), p. 70-87.

GUNDLACH, G. T.; ACHROL, R. S.; MENTZER, J. T. (1995) The structure of commitment in exchange', Journal of Marketing, v. 59, n. Jan, p. 78-92.

GUNDLACH, G.; CADOTTE, E (1994) Exchange interdependence and inter-firm interaction:research in simulated channel setting, Journal of Marketing Research, v. 31, n. Nov, p. 516-532.

GWINNER, K. P.; GREMLER, D. D.; BITNER M. J. (1998) Relational benefits in services industries: The customer's perspective. Journal of the Academy of Marketing Science, v.26, n. 2, p. 101-114.

HAN, S. L.; WILSON, D. T.; DANT, S. P. (1993) Industrial Marketing Management, Buyer-seller relationships today, v. 22, p. 331-338.

HARKER, M. J. (1999) Relationship Marketing Defined? An Examination of Current Relationship Marketing Definitions. Marketing Intelligence and Planning, v. 17, n. 1, p.13-20.

HEIDE, J. B.; JOHN G. (1990) Alliances in industrial purchasing: The determinants of joint action in buyer-supplier relationships. Journal of Marketing Research, v. 27 (February), p. 24-36.

JAP, S. D.; GANESAN S. (2000) Control mechanisms and the relationship life cycle: Implications for safeguarding specific investments and developing commitment.

Journal of Marketing Research, v. 37, p. 227-245.

KLEIN R. L.; QUELCH A. J. (1997). Business to Business Marketing on the Internet. International Marketing Review, v. 14, n. 5, p. 345-361

KUMAR, N.; HIBBARD, J.; STERN, L. (1994) The nature and consequences of marketing channel intermediary commitment, MSI Working Paper.

MOORMAN, C.; ZALTMAN, G.; DESHPANDE, R (1993) Relationships between providers and users of market research: The dynamics of trust within and between organisations, Journal of Marketing Research, v. 29, n. August, p. 314-328.

MORGAN, R. M.; HUNT, S. D. (1994) The commitment-trust theory of relationship marketing. Journal of Marketing, v. 58, n. 3, p. 20-38.

OECD (2006) OECD Information Technology Outlook, Paris.

PEPPERS, D.; ROGERS, M. (1995) A new marketing paradigm: share of customer, 
not market share, Planning Review, v. 23, n. 2, p. 14-28.

PICK, P (1999) Building customer-supplier relationships in electronics, Long Range Planning, v. 32, n. 2, p. 263-272.

PORTER, H. (2001) Strategy and the Internet, Harvard Business Review, v. 79, n. 3, p.63-78.

QUELCH, J. A.; KLEIN, L. R. (1996) The Internet and International Marketing. Sloan Management Review, Spring, p. 60-75.

RATNASINGAM, P (1998) The importance of trust in electronic commerce, Internet Research: Electronic Networking Applications and Policy, v. 8, n. 4, p. 313-321.

RATNASINGAM, P.; PAVLOU, P. (2003) Technology trust in internet-based interorganizational electronic commerce, Journal of Electronic Commerce in Organizations, v. 1, n. Jan- March.

ROTTER, J. B. (1967) A new scale for the measurement of interpersonal trust, Personality, v. 35, n. 4, p. 55-65.

SAMANTA, I. (2008) Innovation Culture Assists Knowledge Management in new e-Ra, in Book WEB 2.0 The Business Model Publisher, Springer De

SAMANTA, I. (2006) The reinforcement of competitiveness of medium sized firms, Applied Research Review Periodical Scientific publication of Technological Institute of Piraeus, v. XI, n. 2, ISSN 1106-4110

SAMIEE, S. (1998) Exporting and the Internet: a conceptual perspective, International Marketing Review, v. 15 n. 5, p. 413-426.

SMITH, J. B.; BARCLAY D. W. (1997) The effects of organizational differences and trust on the effectiveness of selling partner relationships. Journal of Marketing, $v$. 61, p. 3-21.

SPEKMAN, R. E. (1988) Strategic supplier selection: Understanding long-term relationships.Business Horizons, v. 31, p. 75-81.

SPRENG, R.; MACKENZIE, S. B.; OLSHAVSKY, R.W. (1996) A reexamination of the determinants of consumer satisfaction, Journal of Marketing, v. 60, n. 3, p. 15-33.

STOCKDALE, R.; STANDING, C. (2004) Benefits and Barriers of Electronic Marketplace Participation: An SME Perspective. The Journal of Enterprise Information Management, V. 17 N. 4, p. 301-311.

STRAUSS, J.; FROST, R. (1999), Marketing on the Internet: Principles of Online Marketing. Prentice Hall, New Jersey.

WEITZ, B. A.; JAP, S. D. (1995) Relationship marketing and distribution channels, Journal of the Academy of Marketing Science, v. 23, n. 4, p. 305-320.

WETZELS, M.; DE RUYTER, K.; DE BIRGELEN, M. V. (1998) Marketing service relationships: The role of commitment, Journal of Business and Industrial Marketing, v. 13, n. 4/5.

WILLIAMSON, O. E. (1985) The Economic Institution of Capitalism: Firms, Markets, Relational Contracting, The Free Press, New York.

WILSON, D. T. (1995) An integrated model of buyer-seller relationships. Journal of the Academy of Marketing Science, v. 23, n. 4, p. 335-345. 
INDEPENDENT JOURNAL OF MANAGEMENT \& PRODUCTION (IJM\&P)

http://www.ijmp.jor.br

v. 5, n. 3, June - September 2014

ISSN: 2236-269X

DOI: 10.14807/ijmp.v5i3.164

WRIGHT, R. (2004), B2B Marketing, A Step by Step Guide, Prentice Hall, Essex.

ZEITHAML, V. A.; BERRY, L. L.; PARASURAMAN, A. (1996) The behavioural consequences of service quality, Journal of Marketing, v. 60, p. 31-46. 